BULLETIN (New Series) OF THE

AMERICAN MATHEMATICAL SOCIETY

Volume 50, Number 1, January 2013, Pages 147-152

S 0273-0979(2012)01388-5

Article electronically published on October 1, 2012

\title{
ABOUT THE COVER: MARIA GAËTANA AGNESI-A DIVIDED LIFE
}

\author{
GERALD L. ALEXANDERSON
}

The list of women in mathematics in the late 20th century and now is long and includes many mathematicians of great power and achievement. It was not always so. Most accounts of women in mathematics start with Hypatia, but it is not easy to support that choice because she was more likely a philosopher or physicist or astronomer than a mathematician. Most of what we know about her is from secondary or tertiary sources, or from a recent movie (Agora, 2009). We are now told that the mathematical work that is cited was probably done jointly with her father. Her martyrdom seems to make her a historical figure of interest, and that is probably what is best known about her and is best documented. Those who follow Hypatia are often illustrious and very interesting for their mathematics. We also know something of what they accomplished. Here are a few of the better known, in more or less chronological order: Maria Gaëtana Agnesi, Émilie du Châtelet, Sophie Germain, Mary Fairfax Somerville, Ada Byron Lovelace, Florence Nightingale, Mary Boole, Sofia Kovalevskaya, Charlotte Angas Scott, Grace Chisholm Young, and, later, Anna Pell Wheeler, Emmy Noether, and Olga Taussky-Todd. One of the more unusual stories is that of Agnesi (1718-1799).

Today we would not think of Agnesi as a research mathematician. As one of her biographers, Massimo Mazzotti, put it, her book, the Instituzioni analitiche ad uso della giovantù italiana, "was of little significance within the greater genealogy of mathematics, demonstrated by the fact that we do not associate any particular theorem or conceptual advance with her name, only a rather useless curve" 3, p. xi]. That seems a bit harsh. Even though her book was largely an explication of Newton's calculus, it was much used and admired in its day. And though the "Witch of Agnesi" - her "useless" curve - is not a major achievement (and, it happens, was discovered earlier by others anyway), it is known to practically every calculus student as a standard exercise. But more of those matters later.

Agnesi was born into a minor noble, and quite affluent, family in Milan with a father who was ambitious, perhaps something of a social climber. He had twentyone children (by three wives); Maria Gaëtana was the eldest. The second daughter, Maria Teresa, was just as precocious, but in another field. She was a singer, harpsichordist, and composer of some note during her lifetime and her music is still occasionally performed today. Frisi [2, p. 23] claims that as a harpsichordist she "had only a few in Europe who were her equals". Both girls were used by their father to advance the family's reputation in Milanese society. Mazzotti [3, pp. 5-6] writes that at soirées at the Palazzo Agnesi, evenings were not spent at the usual entertainments - gambling and drinking. Instead Maria Teresa would perform music and Maria Gaëtana would carry on disputations with visiting scholars on topics

(C)2012 American Mathematical Society Reverts to public domain 28 years from publication 


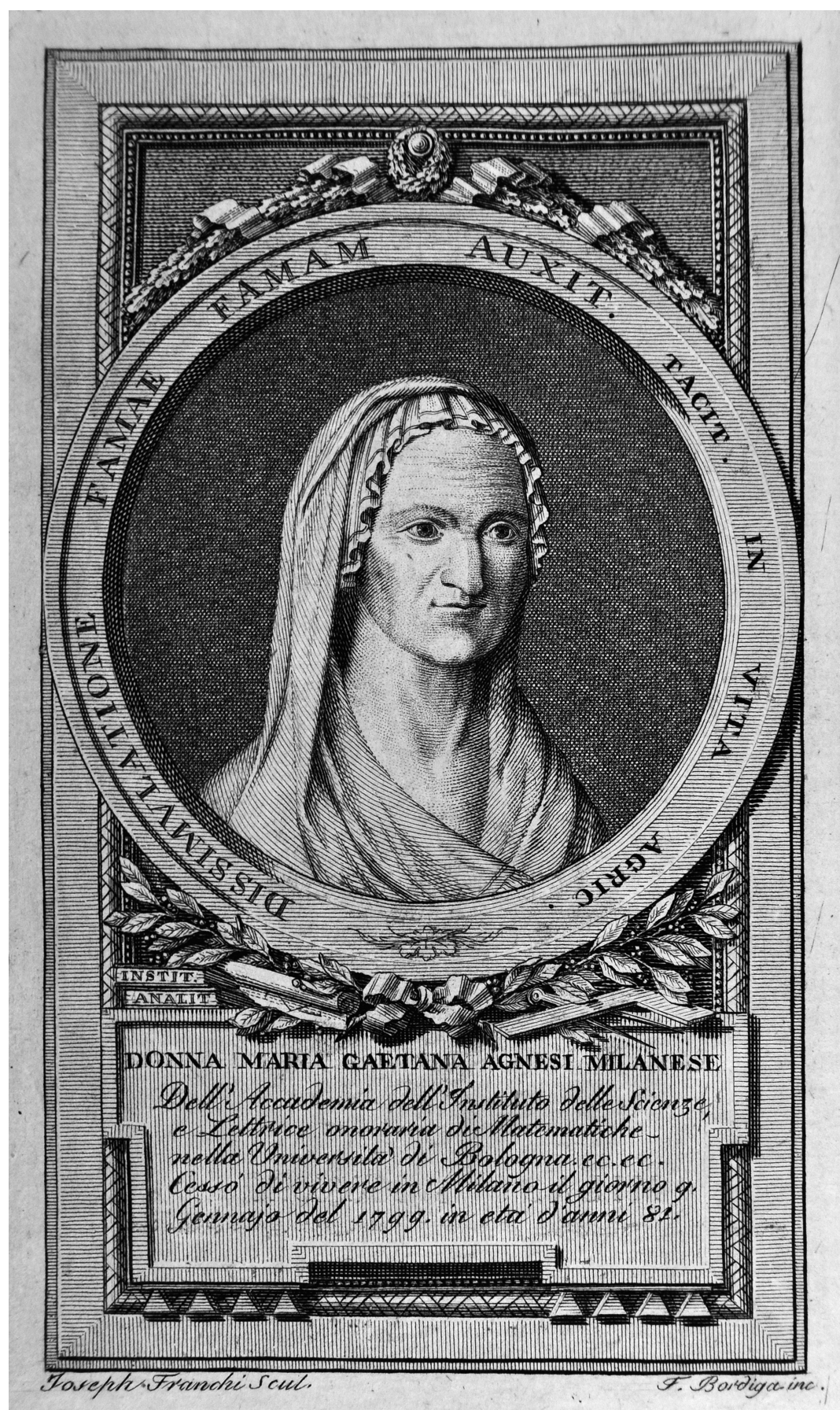

Figure 1. The Cover of this Issue: Maria Gaëtana Agnesi 


\section{ELOGIO STORYCO}

D I

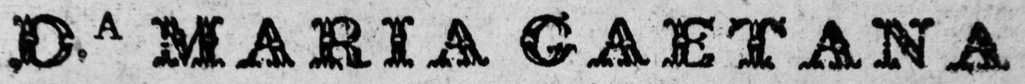
AGN

$M I L A N E S E$

DELL'ACCADEMIA DELL'INSTITUTO DELLE SCIENZE, E LETTRICE ONORARIA DI MATEMATICHE NELLA UNIVERSITA' DI BOLOGNA.

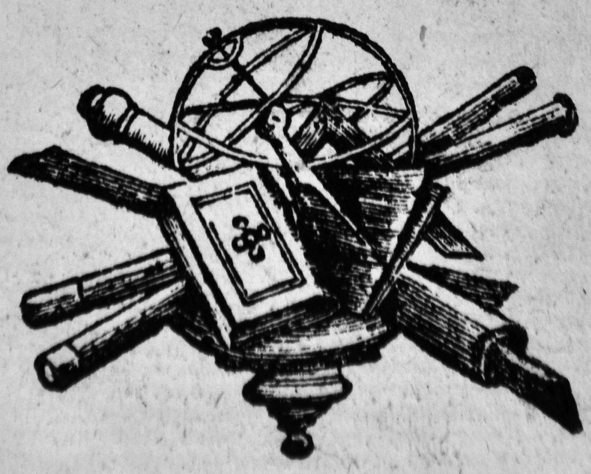

Figure 2. The title page of Frisi's book 
in philosophy and science, in Latin. One observer remarked on her "Ciceronian oratory". As one might suspect from the subtitle of Mazzotti's book, Mathematician of God, Agnesi was more than casually interested in religion. Indeed she was. On theological questions she advised the Archbishop of Milan and she corresponded with Pope Benedict XIV [3, p. xii]. In modern times there has been a movement in her district in Milan to promote her case for sainthood. There are probably few male mathematicians who have been candidates for canonization - not even the mathematician Gerbert who became Pope Sylvester II in 999. (To my knowledge he, like Agnesi, never made it all the way to sainthood. In fact, because of his connection with science and his fight against corruption in the Church, he was accused of being a sorcerer in league with the devil!)

As a young woman, Agnesi had announced to her father that she wanted to enter a convent. In order to dissuade her from this, he promised that she would no longer have to perform at the family soirées and she could pursue religious studies and mathematics. She learned calculus with the help of a tutor, using a text by a little-known French mathematician in Toulon, Charles Renée Reyneau (1656-1728), identified on the title page of his book, Analyse démontrée, only as "un prêtre de l'Oratoire". Was the author's being a priest influential in Agnesi's choice of a textbook? It is possible, since in some of her philosophical work she mentioned the French rational philosopher, Nicolas Malebranche (1638-1715), and it was Malebranche, a member of the French Oratorian order (there were two), who had convinced Reyneau to write his textbook.

The first biographical work about Agnesi, cited earlier, was a eulogy written by a friend, Antonio Francesco Frisi in 1799, the year of her death. It is the frontispiece of the first edition of this book that provides the cover art for this issue 2] (see Figure 1). Here again, curiously enough, the title page (see Figure 2) does not credit the work to Frisi and reads only "Elogio Storico di D. ${ }^{a}$ Maria Gaetana Agnesi Milanese dell'Accademia dell'Instituto delle Scienze, e Lettrice onoraria di matematiche nella Università di Bologna".

Let us move ahead, however, to look at Agnesi's contributions to mathematics, which were crammed into a relatively short middle period of her life. Here Frisi's book is more helpful than Mazzotti's, which gives her mathematics short shrift. Mazzotti, as his subtitle implies, seems more interested in Agnesi's role in the socalled Catholic Enlightenment movement, a subject on which he has written in Isis. Agnesi wrote a commentary on L'Hôptial's Traité analytique des sections coniques (1707), which she never published. A mentor, Ramiro Rampinelli, introduced her to important members of the Riccati family, Jacopo and his two sons Giordano and Vincenzo. It was Jacopo, a count and some years older than Agnesi, who read the first drafts of her manuscript for her great textbook, the Instituzioni analitiche, which was published in 1748, as it turns out, the same year that Euler published his astonishing masterpiece, the Introductio in analysin infinitorum [3, pp. 112-113]. Agnesi's aims were much more modest, of course - a textbook, not a book that would open up whole new areas of mathematics for exploration.

Agnesi, with a penchant for a geometrical view of calculus, was in spirit probably closer to Newton than to the views of the Continental mathematicians: Leibniz, Euler, and the Bernoullis. So it is not surprising, perhaps, that her book attracted the attention of John Colson, the Lucasian Professor at Cambridge, who had translated Newton's De Methodus Serierum et Fluxionum, written in 1671 but 
not published until it came out in English in Colson's translation of 1763 as The Method of Fluxions and Infinite Series. So, knowing Newton's approach to calculus, he would naturally have chosen to make available in English Agnesi's Instituzioni. (A French translation had appeared in 1775.) Unfortunately, Colson died in 1760 so his manuscript lay unpublished until John Hellins, vicar of Potter's-Pury in Northamptonshire, managed to edit Colson's manuscript and get it into print in 1801. The title page identifies the author as "Donna Maria Gaetana Agnesi, Professor of the Mathematicks and Philosophy in the University of Bologna" and the translator as "the Late Rev. John Colson M.A.F.R.S. and Lucasian Professor of the Mathematicks in the University of Cambridge".

This must have been a massive manuscript - the printed translation appears in four books titled (1) The Analysis of Finite Quantities, (2) The Analysis of Quantities Infinitely Small, (3) Of the Integral Calculus, and (4) The Inverse Method of Tangents, a total of 622 quarto pages covering what we would probably call precalculus in the first book and then most topics in a regular calculus sequence in the next three. The list of individual topics looks surprisingly similar to those in modern calculus texts. In his introduction Hellins calls our attention to the qualifications of Colson, pointing out his 1736 translation of Newton, and Colson's being familiar with "the writings of those very ingenious men, Emerson, Mac Laurin [sic], and Simpson." He adds that he "found, after all, the Analytical Institutions of Agnesi to be so excellent that he was at the pains of learning the Italian Language, at an advanced old age, for the sole purpose of translating that work into English; that the British Youth might have the benefit of it as well as the Youth of Italy" [1, p. v].

At a time when most scholarly writing in Europe was in Latin, there is the natural question of why Agnesi chose to write her work in Italian. It is quite possible that in doing so she diminished its impact since any scholar of the time would have known Latin, few Italian. So there is little doubt that the full title of her textbook was carefully chosen to make it clear that it really was intended for young students in Italy who wanted to learn calculus.

Unfortunately, Colson made one error in his translation that has caused speculation for a couple of centuries. Colson mistranslated Agnesi's name for the curve that bears her name: versiera, a synonym for versoria, which means "turning in every direction". But in time this was replaced by versaria signifying a female who is contrary, an adversary; and in Ecclesiastical Latin one of the added meanings was a female who is contrary to God, ... that is, the devil: "a female fiend or goblin", "the devil's grandmother", and other related meanings, the equivalent of the English word "witch" 4. The curve had earlier, possibly in 1701, been referred to as Scala, or scale curve, "because it can serve as a measure of light intensity". This had appeared in work by Guido Grandi, and it had even earlier been mentioned by Fermat.

Shortly after the publication of the Instituzioni in 1748 Agnesi received an appointment to a professorship at the University of Bologna, but by that time she had retired from mathematics and was devoting herself completely for the next forty-five years to good works for the poor. Truesdell reports in [5] that while her name remained on the rolls of the university for forty-five years, she never went to Bologna. During this time, she used up her fortune supporting institutions for the poor and died in 1799 in a poorhouse she directed in Milan. 


\section{REFERENCES}

[1] Agnesi, Maria Gaëtana, Analytical Institutions, London, Taylor and Wilks, 1801.

[2] [Frisi, Antonio Francesco], Elogio Storico di D. ${ }^{a}$ Maria Gaetana Agnesi Milanese, Presso Giuseppe Galeazzi, Milan, 1799

[3] Mazzotti, Massimo, The World of Maria Gaetana Agnesi, Mathematician of God, The Johns Hopkins University Press, Baltimore, 2007. MR2370314 (2008j:01006)

[4] Mulcrone, Thomas F., The names of the curve of Agnesi, Amer. Math. Monthly, 64:5 (May, 1957), 359-361. MR0085163 (18:982a)

[5] Truesdell, Clifford, Maria Gaetana Agnesi, Arch. Hist. Exact Sci., 40:2 (1989), 113-142. MR:1018433 (91k:01014)

Department of Mathematics and Computer Science, Santa Clara University, 500 El Camino Real, Santa Clara, California 95053-0290

E-mail address: galexand@math.scu.edu 